\title{
White pine management in the Ottawa River area of Quebec
}

\author{
by Jean-Louis Brown ${ }^{1}$
}

Over the past few years, white pine management in Quebec has moved from diameter-limit cutting and clear cutting to silvicultural treatments that are more concerned with regeneration of these forests and are better adapted to the structure and phytosanitary condition of stands. The goal is to achieve sustained yield in management units by ensuring forest regeneration and maintenance of, or increase in, stem quality in the residual stands through the application of appropriate treatments by wood fiber users. To continue to improve management methods in order to take maximum advantage of the potential of wood production in existing stands, use of the concept of diameter of maturity instead of age of maturity for determining stem and stand maturity is proposed.

Key words: Forest management, standards, white pine, diameter of maturity, age of maturity

\section{Introduction}

The Outaouais region is the last remaining area in Quebec of extensive white pine stands (Pinus strobus L.), which formerly extended as far eastward as Quebec City before French colonization. It is in the Outaouais region, both on the Ontario and Quebec sides, that one still finds the greatest concentration of white pine stands. This paper outlines white pine management on Quebec lands showing how white pine cutting and management methods evolved before the new Forest Act was enacted in 1986, as well as the shift in white pine management since that Act came into effect. A personal vision of how white pine management can produce the maximum volume of high-quality timber from existing stands will be presented.

\section{Description of the Resources}

In Quebec, white pine is found mainly in the river basin of the Ottawa River, in the Outaouais (07) and AbitibiTémiscamingue (08) administrative regions. These areas contain $88.5 \%$ of Quebec's allowable annual cut of white pine. The allowable annual cut of white pine in these two regions is $616,700 \mathrm{~m}^{3}$ (Table 1 ), of which more than $86 \%$ is found in management units 71, 73 and 81 (Fig. 1). Overall, as of May 31, 1993, white pine and red pine harvest allocations have reached $80.5 \%$ of the annual yield in these management units.

In Quebec, white pine is found in 32 forest cover types (MER 1989). However, in several of these, white pine is a companion species that represents only a small percentage of the canopy. In these cases, it is managed at the same time as the main species. On Crown lands in cover types more favorable to pine production, white pine must be managed according to treatments recognized in the Forest Management Manual, as set out in the Forest Act (R.S.Q., chapter F-4.1) (Editeur Officiel du Québec 1991), which was adopted in December 1986 and came into effect in April 1987. Before going into greater detail about methods of managing white pine as required in the

\footnotetext{
${ }^{1}$ Gouvernement du Québec, ministère des Ressources naturelles, Direction
} de la recherche, 2700 rue Einstein, Sainte-Foy, Québec, Canada G1P 3W8.
L'aménagement du pin blanc au Québec est passé, au cours des dernières années, de la méthode de récolte par la coupe à diamètre limite et la coupe à blanc à des traitements sylvicoles plus soucieux de la régénération de ces forêts et mieux adaptés à la structure et à l'état phytosanitaire des peuplements. L'objectif est d'obtenir le rendement soutenu par unité d'aménagement, en assurant la régénération des forêts et le maintien ou l'augmentation de la qualité des tiges des peuplements résiduels par l'application de traitements appropriés par les utilisateurs de la matière ligneuse. Afin de continuer à améliorer les méthodes d'aménagement, dans le but de tirer parti au maximum du potentiel de production des peuplements en place, l'auteur propose d'utiliser le concept de diamètre de maturité à la place de celui d'âge de maturité pour déterminer la maturité des tiges et des peuplements.

Mots-clés : Aménagement, normes, pin blanc, diamètre de maturité, âge de maturité

latest version of the Forest Management Manual (December 1992), it is helpful to examine how white pine cutting and management methods evolved both before and after the Forest Act was adopted.

\section{White Pine Cutting and Management Methods Before and After Implementation of the 1986 Forest Act}

The Forest Act makes holders of forest management permits responsible for forest renewal. Its aims are forest use and management according to the principles of sustained yield.

To simplify data presentation, the different forest cover types containing white pine are grouped into two strata: hardwoods $(\mathrm{H})$ and softwoods $(\mathrm{S})$. The hardwood stratum includes different stands of tolerant hardwoods containing white pine and mixed stands dominated by intolerant hardwoods (for example, including up to $50 \%$ of white birch with white pine). The softwood stratum groups stands of almost pure white pine or softwoods with white pine, where, in some cases, poplar can make up as much as $25 \%$ of the volume.

Figures $2 \mathrm{a}$ and $2 \mathrm{~b}$ illustrate the relative size of areas treated between 1982 and 1990 according to harvesting methods in the hardwood and softwood strata for management unit 71. Beginning with the 1986-1987 cutting season, when the new Forest Act was implemented, silvicultural treatments became more diverse (strip cutting (StC), seed-tree cutting (STC), selection cutting (SelC), shelterwood cutting (ShC), sanitation cutting (SaC) and thinning (Th)) and replaced the cutting methods commonly used: diameter-limit cutting (DLC) in the hardwood and softwood strata and clear cutting (CC), mainly applied in the softwood stratum. Areas of annual pine harvest are on average 1.3 times larger in the softwood stratum than in the hardwood stratum (Table 2). Also there is from 2 to 9 times more white pine volume harvested in the softwood stratum than in the hardwood stratum. Volumes taken from the softwood stratum are, given equal area, from 2 to 6 times greater than those harvested in the hardwood stratum. 
Table 1. Allowable annual cut and allocation of white and red pines in administrative regions 07 and 08 by management unit ${ }^{1}$

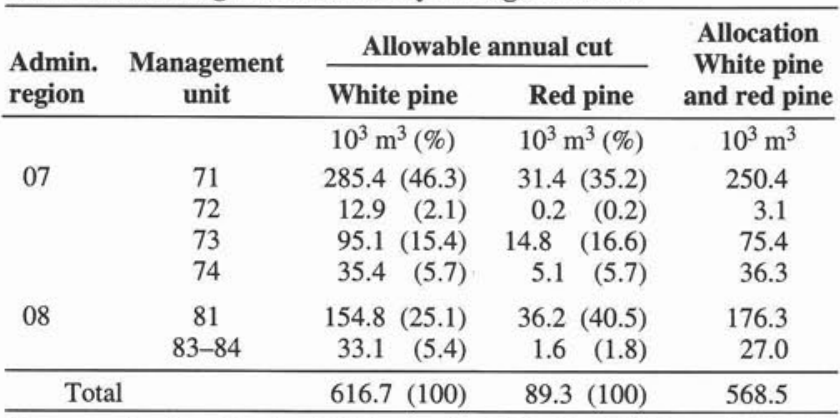

${ }^{1}$ Data provided by: Service de l'évaluation de l'offre (MFO) as of May 31 , 1993.

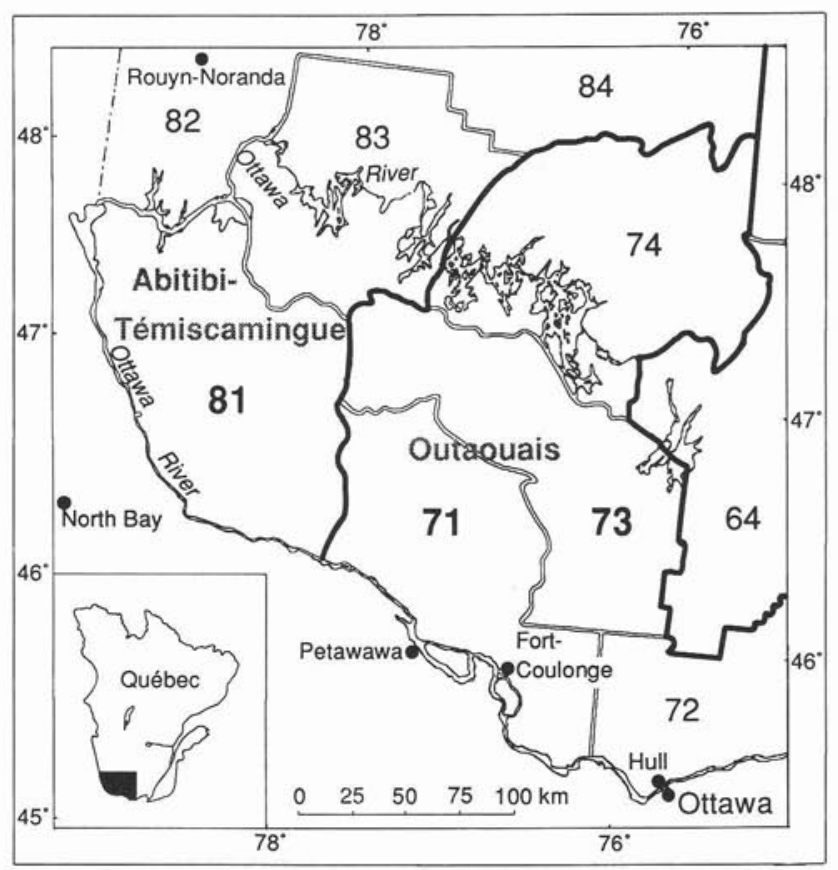

Figure 1. Management units in the Abitibi-Témiscamingue (08) and Outaouais (07) regions, where the highest concentrations of white pine stands are located in Quebec.

Comparison of the percentages of area treated and the volume harvested according to the different types of treatment (Figures 3 and 4), for all strata of white pine $(\mathrm{H}+\mathrm{S})$, also illustrates the shift in cutting modes from 1986-1987. The diameter-limit cutting and, especially, clear cutting over large areas are declining ${ }^{1}$, being replaced mainly by selection cutting, thinning, shelterwood cutting and strip cutting so as to meet the requirements of timber supply and forest management agreements.

To this end, "the Minister shall publish and keep up to date a forest management manual describing, in particular, the method and basis of calculation he uses or intends to use to determine, in respect of a particular forest area, the annual allowable cut and the expected effects of the various silvicultural treat-

${ }^{1}$ The diameter-limit cutting is no longer allowed in the second version (Ministère des Forêts 1992) of the Forest management manual and therefore will be totally eliminated after 1994 , when all timber supply and forest management agreements will have been renewed.

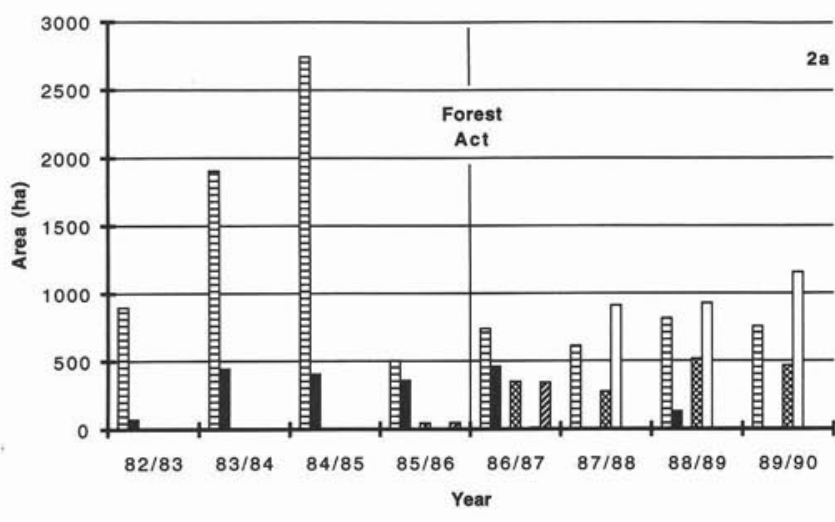

目

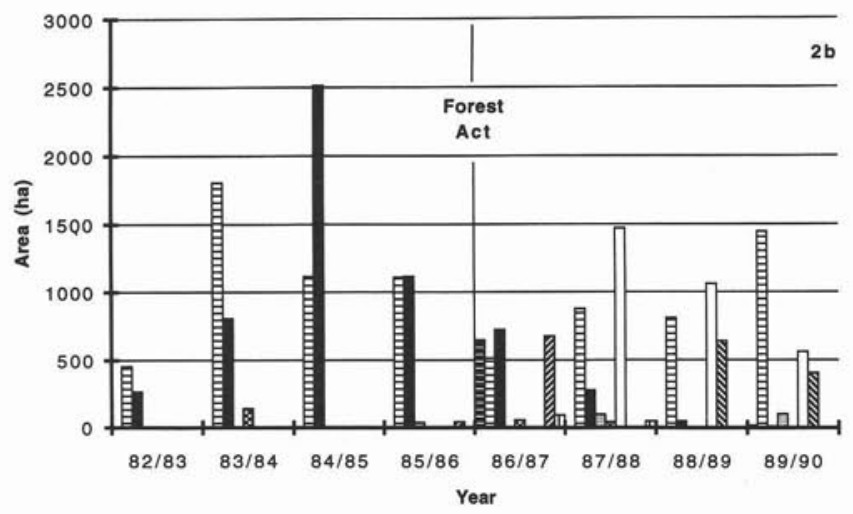

Figure 2. Area of white pine stands harvested under different silvicultural treatments during the $1982-1990$ period (management unit 71). 2a) Hardwood and mixed stands with white pine. 2b) White pine stands and softwood stands with white pine. (Data were obtained from unit forester for this management unit). PC = partial cutting, DLC = diameter-limit cutting, $\mathrm{CC}=$ clear cutting, $\mathrm{STC}=$ seed-tree cutting, $\mathrm{StC}=$ strip cutting, $\mathrm{SelC}=$ selection cutting, $\mathrm{ShC}=$ shelterwood cutting, $\mathrm{Th}=$ thinning, $\mathrm{SaC}=$ sanitation cutting.

ments on the allowable cut." (R.S.Q., chapter F-4.1, s. 29). These treatments are those retained by a committee composed of representatives of the ministère des Forêts and industry to meet goals set by the ministère. The process aims, in a way, at achieving a consensus that strikes a balance between the requirements of healthy silviculture and those of the economic imperatives of the moment.

Table 3 shows the 8 silvicultural treatments retained for stands or areas given priority for production of white and red pine. These different treatments will be applied according to the age, structure, composition, quality and sanitary condition of stands to be managed. These silvicultural treatments may be admitted as payment of dues (credit of stumpage) if they are applied in accordance with the annual forest management plan and the standards. The annual regulation fixes the credits of stumpage for each silvicultural treatments.

The first five treatments (regeneration cutting, shelterwood cutting, plantation and seeding under shelter cone, precommercial and commercial thinning) apply to even-aged stands. The two following treatments (selection cutting, pre-selection cutting) are used in uneven-aged stands, while the last one, improvement cutting, applies to both stand structures. 
Table 2. Ratio between softwood (S) and hardwood $(\mathrm{H})$ strata for the areas treated and the volumes harvested, and the average volume harvested per ha in the $\mathrm{S}$ and $\mathrm{H}$ strata in management unit 71

\begin{tabular}{|c|c|c|c|c|}
\hline \multirow{2}{*}{$\begin{array}{l}\text { Cutting } \\
\text { year }\end{array}$} & \multirow{2}{*}{$\frac{\text { S Area }}{\text { H Area }}$} & \multirow{2}{*}{$\frac{\text { S Volume }}{\text { H Volume }}$} & \multicolumn{2}{|c|}{$\begin{array}{l}\text { Average volume harvested } \\
\qquad\left(\mathrm{m}^{3} \mathrm{ha}^{-1}\right)\end{array}$} \\
\hline & & & $\mathbf{S}$ & $\mathbf{H}$ \\
\hline $82 / 83$ & 0.75 & 2.31 & 45.7 & 14.8 \\
\hline $83 / 84$ & 1.17 & 5.79 & 35.1 & 7.1 \\
\hline $84 / 85$ & 1.15 & 2.44 & 22.0 & 10.4 \\
\hline $85 / 86$ & 2.43 & 7.50 & 35.8 & 11.6 \\
\hline $86 / 87$ & 1.43 & 5.42 & 27.9 & 7.4 \\
\hline $87 / 88$ & 1.57 & 9.06 & 37.2 & 6.4 \\
\hline $88 / 89$ & 1.07 & 5.79 & 37.3 & 6.9 \\
\hline $89 / 90$ & 1.07 & 4.50 & 26.7 & 6.4 \\
\hline $\bar{x}$ & $1.33 \pm 0.51$ & $5.4 \pm 2.3$ & $33.5 \pm 7.5$ & $8.9 \pm 3$ \\
\hline
\end{tabular}

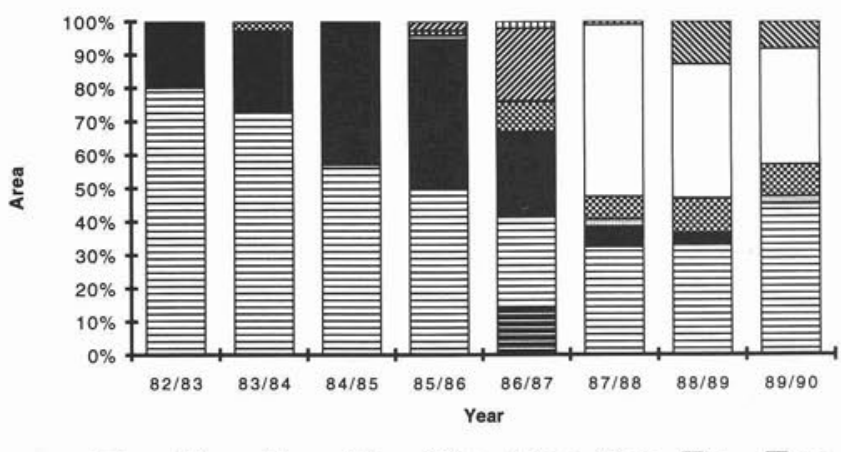

E

Figure 3. Percentage of area harvested annually by silvicultural treatment during the $1982-1990$ period (management unit 71 ). (Data were obtained from unit forester from this management unit). $\mathrm{PC}=$ partial cutting, DLC = diameter-limit cutting, CC = clear cutting, STC = seed-tree cutting, $\mathrm{StC}=$ strip cutting, $\mathrm{SelC}=$ selection cutting, $\mathrm{ShC}$ $=$ shelterwood cutting, $\mathrm{Th}=$ thinning, $\mathrm{SaC}=$ sanitation cutting .

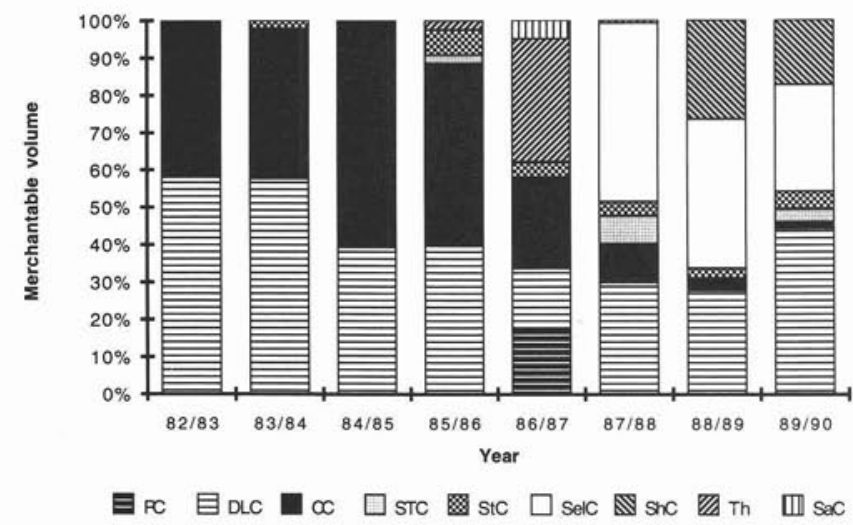

Figure 4. Percentage of volume harvested annually by silvicultural treatment during the 1982-1990 period (management unit 71). (Data were obtained from unit forester from this management unit). PC = partial cutting, DLC = diameter-limit cutting, CC = clear cutting, STC = seed-tree cutting, $\mathrm{StC}=$ strip cutting, $\mathrm{SelC}=$ selection cutting, $\mathrm{ShC}$ $=$ shelterwood cutting, $\mathrm{Th}=$ thinning, $\mathrm{SaC}=$ sanitation cutting .

For the regeneration cutting, with or without seeding under shelter cone, the goals to achieve two years after treatment are, for the major and commercial species, a stocking ${ }^{2}$ after cutting $\left(\mathrm{S}_{\mathrm{ac}}\right)$ that is equal to or larger than the stocking before cutting $\left(\mathrm{S}_{\mathrm{bc}}\right)$. Eight years after cutting in red pine and 20 years after cutting in white pine, the stocking level of freely-growing young trees must be equal to or greater than that of the original stand.

For the shelterwood cutting, the stocking level in red and white pine must be, after the removal cutting, equal to or greater than that of the original stand after 2 and 8 years, respectively.

Where natural regeneration is deficient, the site is returned to production through planting or seeding under shelter cone to reconstitute, according to the production goals, either a stand with a stocking level equal to that of the original stand or the equivalent of a plantation. In the latter case, the goal is to have from 1875 to 2750 seedlings ha ${ }^{-1}$, spaced $1.4 \mathrm{~m}$ or more apart (goal of $2 \mathrm{~m} \times 2 \mathrm{~m}$ ). For white pine, the goal is to have 1875 or more freely-growing young stems 20 years after the treatment.

Precommercial thinning is applied in young stands aged between 5 and 15 years. The goal of this treatment is to obtain between 300 and 500 well-spaced crop trees ha ${ }^{-1}(5 \mathrm{~m} \times 5 \mathrm{~m})$ immediately after treatment.

Commercial thinning is conducted in stands aged 90 years or less. Immediately after treatment, the residual basal area (BA) for the major species must be at least $16 \mathrm{~m}^{2} \mathrm{ha}^{-1}$ of well-spaced stems, and the BA removed must be 30 to 40 percent of the initial merchantable BA.

Uneven-aged stands with a stem distribution tending towards an "inverse J" with crop trees in each diameter class can be subjected to selection cutting. The residual BA for merchantable stems must be at least $16 \mathrm{~m}^{2} \mathrm{ha}^{-1}$ immediately after cutting. The percentage of the residual BA in stem of grade I (vigorous and quality tree) must increase, while the removed BA must be between 25 and 35 percent of the initial BA.

Preselection cutting is applied in uneven-aged stands where the stem quality and the stand's density are low, provided that there are crop trees from the principal species in each diameter class. The residual merchantable BA must be at least $12 \mathrm{~m}^{2}$ $\mathrm{ha}^{-1}$ immediately after cutting, and the percentage of the BA in grade-I stems must be higher than it was before cutting. The removed BA is set at 20 to 30 percent of the initial BA.

Improvement cutting, which replaces diameter-limit cutting, is the harvest of stems with a diameter equal to or higher than the diameter limit set for each species. Immediately after cutting, the residual merchantable BA must be at least $12 \mathrm{~m}^{2}$ $\mathrm{ha}^{-1}$ and the percentage of the BA in grade-I trees must be equal to or higher than what it was before harvesting. The removed BA must be between 20 and 35 percent of the initial basal area.

All these silvicultural treatments are aimed at improving residual stand quality, maintaining or increasing their productivity and also encouraging regeneration in a natural way or a return to production through planting, seeding or infilling poorly regenerated areas. In the past, the cutting methods used (clear cutting and diameter-limit cutting) produced highly variable results (Huot 1987). It became more and more urgent to resolve the problems of natural regeneration and degradation in residual stands after several diameter-limit cuttings. This is what the new Forest Act is designed to remedy. These treatments are adapted to present silvicultural and economic conditions. They can be improved as silvicultural knowledge and

${ }^{2}$ For natural regeneration in white pine and red pine, stocking is estimated with $25 \mathrm{~m}^{2}$ quadrats; for artificial regeneration the quadrats are $4 \mathrm{~m}^{2}$. 


\begin{tabular}{|c|c|c|c|}
\hline Silvicultural treatment & $\begin{array}{l}\text { Stand } \\
\text { structure }\end{array}$ & Objectives & $\begin{array}{l}\text { Time limit } \\
\text { after treatment }\end{array}$ \\
\hline \multirow[t]{2}{*}{$\begin{array}{l}\text { (1) Regeneration cutting and seeding under } \\
\text { shelter cone }\end{array}$} & even-aged & $\begin{array}{l}\text { For major species and commercial species } \\
\mathrm{S}_{\mathrm{ac}} \geq \mathrm{S}_{\mathrm{bc}}\end{array}$ & 2 yrs \\
\hline & & $\begin{array}{l}\text { Young freely-growing trees } \\
\mathrm{S}_{\mathrm{ac}} \geq \mathrm{S}_{\mathrm{bc}}\end{array}$ & $\begin{array}{l}\text { rP } 8 \text { yrs } \\
\text { wP } 20 \text { yrs }\end{array}$ \\
\hline (2) Shelterwood cutting (after removal cutting) & even-aged & $\begin{array}{l}\text { Young freely-growing trees } \\
\mathrm{S}_{\mathrm{ac}} \geq \mathrm{S}_{\mathrm{bc}}\end{array}$ & $\begin{array}{l}\text { rP } 2 \text { yrs } \\
\text { wP } 8 \text { yrs }\end{array}$ \\
\hline \multirow[t]{2}{*}{ (3) Plantation and seeding under shelter cone } & & $\begin{array}{l}1875-2750 \text { seedlings } \mathrm{ha}^{-1} \text { spaced } \geq 1.4 \mathrm{~m} \\
2 \mathrm{~m} \times 2 \mathrm{~m}\end{array}$ & After planting \\
\hline & & $\geq 1875$ freely-growing young trees ha-1 & $\begin{array}{l}\text { rP } 8 \text { yrs } \\
\text { wP } 20 \text { yrs }\end{array}$ \\
\hline (4) Precommercial thinning & 5 to 15 years old & $\begin{array}{l}300 \text { to } 500 \text { well spaced crop trees ha }{ }^{-1} \\
5 \mathrm{~m} \times 5 \mathrm{~m}\end{array}$ & $\begin{array}{l}\text { Immediately } \\
\text { after thinning }\end{array}$ \\
\hline \multirow[t]{2}{*}{ (5) Commercial thinning } & $\begin{array}{c}\text { even-aged } \\
\leq 90 \text { years old }\end{array}$ & $\begin{array}{l}\text { For major species } B A \geq 16 \mathrm{~m}^{2} \mathrm{ha}^{-1} \\
\text { in well-spaced crop trees }\end{array}$ & $\begin{array}{l}\text { Immediately } \\
\text { after thinning }\end{array}$ \\
\hline & & $\mathrm{BA}$ removed $=30$ to $40 \%$ of stand $\mathrm{BA}$ & \\
\hline \multirow[t]{2}{*}{ (6) Selection cutting } & $\begin{array}{l}\text { uneven-aged J-shaped } \\
\text { diameter distribution with } \\
\text { crop trees of major species } \\
\text { in each diameter class }\end{array}$ & $\begin{array}{l}\text { Residual BA } \geq 16 \mathrm{~m}^{2} \mathrm{ha}^{-1} \text { for } \\
\text { merchantable trees } \\
\text { Grade I trees increased as \% of BA }\end{array}$ & $\begin{array}{l}\text { Immediately } \\
\text { after cutting }\end{array}$ \\
\hline & & $\begin{array}{l}\text { BA removed is between } 25 \text { and } 35 \% \\
\text { of initial BA }\end{array}$ & \\
\hline \multirow[t]{2}{*}{ (7) Preselection cutting } & $\begin{array}{l}\text { uneven-aged J-shaped } \\
\text { diameter distribution with } \\
\text { crop trees of major species } \\
\text { in each diameter class }\end{array}$ & $\begin{array}{l}\text { Residual BA } \geq 12 \mathrm{~m}^{2} \mathrm{ha}^{-1} \text { for } \\
\text { merchantable trees } \\
\text { Grade I trees increased as \% of BA }\end{array}$ & $\begin{array}{l}\text { Immediately } \\
\text { after treatment }\end{array}$ \\
\hline & & $\begin{array}{l}\text { BA removed between } 20 \text { and } 30 \% \\
\text { of initial BA }\end{array}$ & \\
\hline \multirow[t]{4}{*}{ (8) Improvement cutting } & & $\begin{array}{l}\text { Harvested trees have } \mathrm{DBH} \geq \text { diameter } \\
\text { limit set for each species }\end{array}$ & $\begin{array}{l}\text { Immediately } \\
\text { after cutting }\end{array}$ \\
\hline & & $\begin{array}{l}\text { Residual BA } \geq 12 \mathrm{~m}^{2} \mathrm{ha}^{-1} \text { for } \\
\text { merchantable trees }\end{array}$ & \\
\hline & & $\begin{array}{l}\text { Grade I trees increased as \% of BA or } \\
\text { same as before cutting }\end{array}$ & \\
\hline & & $\begin{array}{l}\text { BA removed is between } 20 \text { and } 35 \% \\
\text { of initial BA }\end{array}$ & \\
\hline
\end{tabular}

$\mathrm{S}_{\mathrm{ac}}=$ Stocking after cutting, $\mathrm{S}_{\mathrm{bc}}=$ Stocking before cutting, $\mathrm{BA}=$ basal area, $\mathrm{wP}=$ White pine, $\mathrm{rP}=$ Red pine.

economic conditions change in order to maximize the strong potential production of white pine.

\section{The Diameter of Maturity : A Concept for Obtaining Optimal Yield from Existing White Pine Forests}

Maximizing the production of the remaining pine stands, which still cover relatively large areas in this region of Quebec, is vitally important.

White pine is a long-lived species ( 450 years and more) (Harlow et al. 1979) capable of reaching large diameters (more than $1 \mathrm{~m}$ $\mathrm{DBH}$ on good sites) more or less rapidly according to the degree of competition present. It can remain suppressed for up to 40 years (Horton and Bedell 1960) or even 60 years (Brown 1984). After being released, suppressed individuals can grow rapidly, reaching a large size and producing a significant volume of quality timber (Brown 1984).

Given these characteristics, the maturity of white pine does not depend so much on its age as on the size it can reach on a given site. Indeed, for a given diameter the age of the stand or trees will be larger or smaller depending on the degree of competition to which the trees have been subjected in the past. For these reasons, the use of the concept of "diameter of maturity", defined by the stem diameter of dominant tree, when its mean annual increment peaks is suggested. The diameter of maturity will vary according to site quality.

An analysis of the growth of a few large white pine stems demonstrates the strong production potential of this species and the importance of not harvesting its stands prematurely. Brown (1992) has shown with the growth of six white pine aged 164 to 204 years, with DBH of 46 to $70 \mathrm{~cm}$, and growing on a shallow till, that the mean annual increment in volume continues to increase with increasing diameter, whatever the age of the stem. Periodic increment for the last decade varied from 340 to $700 \mathrm{dm}^{3}$ of high-quality knot-free timber. These increment volumes correspond to volume of stem DBH of 24 to $34 \mathrm{~cm}$. In addition, current annual increment during the last decade being 1.6 to 3 times larger than the mean annual increment, the latter should continue to increase for several decades. Other observations, made on deep till, show even larger periodic incre- 
ment that can reach $1 \mathrm{~m}^{3}$ over 10 years for dominant trees with DBH of 50 to $70 \mathrm{~cm}$ (J.L. Brown, unpublished data). These trees are growing on fertile soils and have generally endured at the outset strong competition from hardwoods. They are characterized by narrow annual rings at the centre and by a relative high age for a given diameter.

Since volume increment is controlled by the degree of competition and by stem size, the largest increments occur in stems with larger diameters. These stems, even if they have endured strong competition over a long period of time, later show annual rings that thicken considerably as the canopy opens up and these trees reach a position of dominance. Because of this increase in ring thickness and the fact that this increment is added around an ever-larger cylinder, i.e. the stem, the volume increment will continue to increase for a long time, even once the diameter increment has begun to decrease.

\section{Conclusion}

A white pine tree is an expanding timber factory. Its production increases in volume and quality as it grows in diameter, until it reaches its diameter of maturity. This illustrates the importance of not harvesting healthy white pine stems prematurely, if we are to avoid unduly reducing the volume that existing stands of white pine can produce.

Depending on the structure, composition, dynamics and health of pine stands, and also management objectives, several silvicultural treatments are required by management standards for white pine in Quebec's public lands. However, to obtain the optimum yield in volume and in quality from these stands, these different treatments must be applied in such a way as to allow the greatest possible number of stems to reach their optimum diameter or diameter of maturity.

Thinnings that begin early in the life of the stand will pre- vent stagnated growth and accelerate the process towards stand maturity. Removal cutting should only be conducted once the stand has reached its diameter of maturity.

\section{Acknowledgments}

The author would like to thank the following people at the MFO: André Beaupré, Julie Thiboutot, Olivier Lesquir and Serge Fiola for providing data, and Alain Gosselin, Michel Tremblay and Christian Godbout for reviewing the manuscript.

\section{References}

Brown, J.-L. 1984. Testament d'un vieux pin blanc. For. Chron. 60: 269-272.

Brown, J.-L. 1992. Principes et normes d'aménagement des peuplements naturels de pin blanc et de pin rouge proposés pour le Québec. Ministère des Forêts, Direction de la recherche, note de recherche forestière no. 46,10 p.

Éditeur Officiel du Québec. 1991. Forest Act. R.S.Q. , chapter F4.1 (Updated to 17 September 1991).

Harlow, W.M., E.S. Harrar and F.M. White. 1979. Textbook of dendrology, 6th ed. McGraw-Hill. New York. 510 p.

Horton, K.W. and G.H.D. Bedell. 1960. White and red pine. Ecology, Silviculture and Management. Canada, Dept. of North. Aff. and Nat. Res., For. Branch, Bull. 124, 185 p.

Huot, M. 1987. Régénération naturelle du pin blanc après coupe à diamètre-limite dans le sud-ouest du Québec. M.Sc.F. Thesis, Fac. For et Géod., Univ. Laval, Québec, 76 p.

M.E.R. 1989. Normes d'inventaire forestier. Les Publications du Québec. Québec. 177 p.

Ministère des Forêts. 1992. Manuel d'aménagement forestier. Gouv. du Québec, MFO, 250 p.

Ministère des Forêts. 1993. Instructions relatives à l'application du règlement sur la valeur des traitements sylvicoles admissibles en paiement des droits 1993-1994. Gouv. du Québec, MFO FQ93-3048, 161 p. 